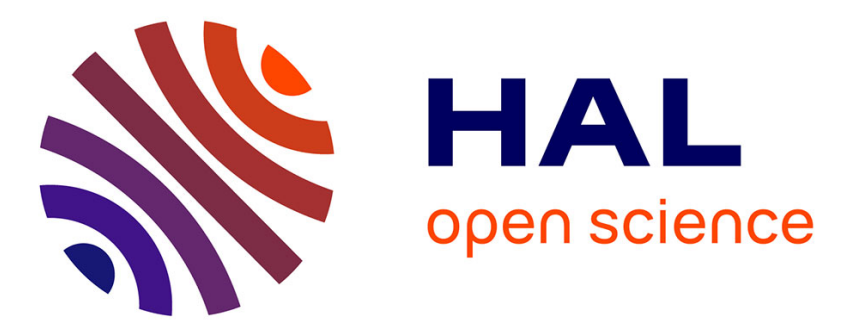

\title{
Heritage and Cultural Policy in France under the Fifth Republic
}

Philippe Poirrier

\section{To cite this version:}

Philippe Poirrier. Heritage and Cultural Policy in France under the Fifth Republic. International Journal of Cultural Policy, 2003, pp.215-225. halshs-00628926

\section{HAL Id: halshs-00628926 \\ https://shs.hal.science/halshs-00628926}

Submitted on 4 Oct 2011

HAL is a multi-disciplinary open access archive for the deposit and dissemination of scientific research documents, whether they are published or not. The documents may come from teaching and research institutions in France or abroad, or from public or private research centers.
L'archive ouverte pluridisciplinaire HAL, est destinée au dépôt et à la diffusion de documents scientifiques de niveau recherche, publiés ou non, émanant des établissements d'enseignement et de recherche français ou étrangers, des laboratoires publics ou privés. 
Source : Philippe Poirrier, Heritage and Cultural Policy in France under the Fifth Republic, International Journal of Cultural Policy, 2003, $\mathrm{n}^{\circ}$ 9-2, p. 215-225.

\title{
Heritage and Culture Policy in France under the Fifth Republic
}

\author{
by \\ Philippe Poirrier \\ Institute for Contemporary History, University of Burgundy
}

There are several ways of treating the history of "heritage". In the French historical tradition, four approaches at least have been heavily exploited. One seminal study defines the concept longitudinally in terms of religion, the monarchy, the family, the nation, the administration and science. ${ }^{1}$ Another essay uses allegory in an attempt to penetrate the proclaimed, avowed or unspoken motives underlying the notion of heritage. ${ }^{2}$ Another work uses the criterion of restoration to determine when a historical monument falls into the category of heritage. $^{3}$ Fourth, a recent ground-breaking treatise considers heritage in historical and archaeological practice as reflecting representations of citizenship and the nation. ${ }^{4}$

Our angle of attack is somewhat different, even though it draws on the above approaches for its conclusions and suggestions for research. What interests us is the role of official culture policies - those pursued by the State, particularly - in the development of the idea of heritage. ${ }^{5}$

The history of official heritage policies, in the second half of the twentieth century, still remains to be written, and the practical groundwork has not yet been done. The subject is vast indeed. ${ }^{6}$ It is true that a prolific literature exists, but it

\footnotetext{
1 BABELON, J-P., CHASTEL, A., La notion de patrimoine, Editions Liana Levi, Paris, 1994. (First published in 'Revue de l'art', 1980.)

${ }^{2}$ CHOAY, F., L'allégorie du patrimoine, Seuil, Paris, 1992.

3 BERCE, F., Des Monuments historiques au Patrimoine du XVIIIe siècle à nos jours, Flammarion, Paris, 2000.

${ }^{4}$ POULOT, D., Patrimoine et musées. L'institution de la culture, Hachette, Paris, 2001.

5 The work entailed received the backing of the History Committee of the French Ministry of Culture. A less detailed version was presented in November 2001 at the "Conversations on Heritage" chaired by Henry Rousso and organized by the Heritage and Architecture Directorate of the Ministry of Culture. Our gratitude goes to Augustin Girard and Christian Pattyn who kindly read through the present article.

${ }^{6}$ For a general stocktaking, see POIRRIER, P., Bibliographie de l'histoire des politiques culturelles, France, XIXe-XXe siècles, La Documentation Française - Comité d'histoire du Ministère de la Culture, Paris, 1999, and POIRRIER, P., VADELORGE, L., Histoire des
} 
falls into two categories. A good deal of it is administrative in nature. The Ministry of Culture turns out this "grey prose" in great quantities. It is often concerned with directives and standards. The writers are themselves involved in heritage protection. The technical prescriptions contained in it often tend to obscure the public policy background. For another thing, this literature is, not surprisingly, upbeat in tone. The other category comprises writings of a partisan character which treat heritage as an element in the debate for or against the "Cultural State". Its adversaries currently seem to have the upper hand. For over ten years now, they have excoriated the "Culture State", the "cultural farce", and the "French utopia".

The State operates in a dialectical relation with society. All public policies, including cultural policy, indeed have a certain life of their own, but it would be vain to think that the State has acted independently from the great currents that have moulded French society since the post-war years. ${ }^{8}$

The State is not a faceless entity. The "State" is in fact a collection of various players who join, or compete, in building public policy. In the case of heritage, they may be politicians, civil servants, scientists or economists. It is often difficult to distinguish between the scientific and economic dimensions. One of the shaping factors of public heritage policy is the very close link between heritage "science" and heritage "awareness".

We shall examine three periods during which governments have fashioned the notion of heritage since 1959: first, the Malraux episode; second, the swing of the 1970s; third, the consolidation of the 1980s.

\section{A Malraux heritage epiphany?}

Let us begin with the Malraux decade. When the Ministry for Cultural Affairs administration was put together in 1959, the new organization chart clearly displayed the importance accorded to heritage services. Not only was there a sub-Directorate for Historic Places and Monuments; there were also a sub-Directorate for Civilian Buildings within the Architecture Directorate, a Museum Directorate within the General Directorate for Art and Literature, and an Archives Directorate. Ever since the 1950s, the State's hold has been embodied in the provinces by the regional "Buildings of France Conservatories", which are deconcentrated branches of the Architecture Directorate. They were intended, among other things, to counter the influence, deplored even before the Second World War, of the historical monument chief architects. The regional

politiques du patrimoine. Une histoire à écrire, in "Les Cahiers de la ligue urbaine et rurale", 2nd half, 2002.

${ }^{7}$ See the openly polemical but well-informed studies by Jean-Michel Leniaud: L'utopie française. Essai sur le patrimoine, Ed. Mengès, Paris, 1992, and Chroniques patrimoniales, Norma, Paris, 2001.

${ }^{8}$ POIRRIER, P., L'Etat et la culture en France au XXe siècle, Le Livre de Poche, Paris, 2000.

${ }^{9}$ NORA, P. (Ed.), Science et conscience du patrimoine, Fayard-CNMHS, Paris, 1997. 
Conservatories served as a nucleus for the gradual installation of the Ministry for Cultural Affairs' regionalised services. ${ }^{10}$

The Ministry has a long history, going back at least to the July Monarchy in the 19th century. Its main features are worth remembering, since they have left an enduring mark on its pattern of administration. It is State-run, centralised and, since the early days of the Third Republic, has tended to sideline local officials and associations. The Ministry's development corresponded to a use of culture as an instrument - a function inherent in all government culture policies. François Guizot, King Louis Philippe's Minister of the Interior, wished to "re-knit the threads of time" between the old pre-Revolutionary France and the France born of the Revolutionary ten years. This doctrine led to the creation of an Inspectorate then a Department for Historical Monuments in 1830, as well as the founding of the Versailles History Museum. ${ }^{11}$ These services, in addition to their age, were backed by a large body of law, notably the Acts of 1887 and 1913, enacted under the Third Republic. ${ }^{12}$ Their centralisation was accentuated by the legislation introduced by the Vichy Government from 1940 to 1944 . State privilege was further enhanced by the absence of parliamentary oversight. Veteran programmes, especially in the field of archaeology, could thus come to fruition. With the Liberation and the restoration of Republican legitimacy, a whole slate of heritage laws received new approval.

The cultural administration has amassed an impressive store of technical knowledge. It has raised the restoration of historical monuments to the status of a genuine science. The services involved are heavy spenders - at the eve of the 1960s, they ate up more than 60 per cent of the young Ministry of Cultural Affairs' budget. They also benefit from the expertise of staff trained in France's national écoles, ranging from the Ecole nationale des Chartes to the Ecole du Louvre.

But back to Malraux. ${ }^{13}$ When Malraux attempted to break with the "Fine Arts" mentality, heritage was far from being a priority. What the Minister really wanted was to encourage contemporary art and stake his policy on new creation. In another effort to shake off the "Fine Arts" tradition, he embarked on an ambitious cultural action programme expressed in large measure through the building of "maisons de la culture". Yet the report written in March 1968 by Antoine Bernard, head of Malraux's private office, does not depart from conventional "Fine Arts" ideas in its treatment of historical monuments and

${ }^{10}$ BODIGUEL, J-L., L'implantation du Ministère de la Culture en région. Naissance et développement des directions régionales des affaires culturelles, La Documentation Française Comité d'histoire du Ministère de la Culture, Paris, 2000.

11 PIRE, J-M., Les originesdu volontarisme culturel français. Sociologie de la politique culturelle sous la monarchie de Juillet, sociology thesis, University of Paris VII, 1999.

${ }^{12}$ See the compendium published in the series "Retour aux textes": POIRRIER, P., Les politiques culturelles en France, La Documentation Française, Paris, 2002.

${ }^{13}$ For an authoritative account, see LAURENT, X., La politique du patrimoine monumental d'André Malraux à Michel Guy (1958-1974), paleographic archivist diploma thesis, Ecole Nationale des Chartes, 2002. 
heritage in the broad sense. ${ }^{14}$ Recent research into cultural policy confirms these observations. The most thought-provoking studies, by Philippe Urfalino and Vincent Dubois, published in 1996 and 1999 respectively, cover cultural policy in the 1960 s without the slightest mention of heritage affairs. ${ }^{15}$

A few measures, however - in particular, three series of laws undoubtedly helped to enlarge the notion of heritage. First, there was the 1962 Act on "preserved sectors". It formed part of the Historic Monuments Service's efforts to expand its field of competence, which had begun with the 1930 Act concerning historic places and continued with the 1943 text on controlling the vicinity of these places. The Ministry for Construction played as important a role as the Ministry for Cultural Affairs in generating the 1962 Act, even though Malraux symbolically took the credit for it. The Act was one component in a long-term design for planned and controlled town planning. It introduced long and complicated procedures that quickly became the preserve of associations which sprang into action in the cities. It had the merit, in any case, of initiating a significant shift from the purely monumental to an insertion in the urban context.

A second style of measure was exemplified by the launching in 1964 of the "General Inventory of France's Monuments and Artistic Treasures". The very title betokens a continuation of the "Fine Arts" approach and its tastes. Yet it can equally be seen as a challenge to the Historic Monument Service, a way of breaking Paris's monopoly on expertise, or a goal-oriented project incorporated into the government's Plan. ${ }^{16}$ The Inventory was to play a very important role in the thinking about rules and standards that was to come. The outcome was a set of principles for analysing the different heritage fields. The fact of covering the whole range of what had been built made it possible to broaden the notion of heritage. André Chastel's strategy clearly was to use the Inventory to reform the subject of "History of Art", which in France was handicapped by its separatism, internal divisions and refusal to regard the world outside. The Inventory no doubt stimulated greater public awareness of what heritage meant. Beginning in 1966, hundreds of local voluntary workers participated in the work of preparing the Inventory.

A third step extended the chronological sense of heritage. Malraux's special relationship with Le Corbusier resulted in the protection of the architect's work in Ronchamp and Chandigar. Such a decision was exceptional in character. The Marseilles complex was added to the supplementary Inventory in October 1964 and the Villa Savoye was added in December 1965. Other protective measures followed from 1965 to 1967 . The case of Le Corbusier apart, the Architecture Directorate's thinking had evolved, with the setting up in April 1963 of a "Modern Monuments Commission" entrusted with choosing "specimen monuments at the root of certain movements in modern architecture". The idea

\footnotetext{
${ }^{14}$ BERNARD, A., Le Ministére des Affaires Culturelles et la mission culturelle de la collectivité, mars 1968, La Documentation Française, Paris, 1989.

${ }^{15}$ URFALINO, P., L'invention de la politique culturelle, Comité d'histoire du Ministère de la Culture - La Documentation Française, Paris, 1996; DUBOIS, V., La politique culturelle: genèse d'une catégorie d'intervention publique, Belin, Paris, 1999.

${ }^{16}$ BALSAMO, I., André Chastel et "l'aventure" de l'Inventaire, in P. NORA (Ed.), Science et conscience du patrimoine, Fayard - Editions du patrimoine, Paris, 1997, pp257-267.
} 
was not to obtain a representative sample but, as Xavier Laurent puts it, "to support an imaginary genealogy of the modern movement." The High Commission for Historical Monuments offered stiff resistance, and the main beneficiaries of the protection procedures were Le Corbusier and Auguste Perret.

The real changeover, the real transformation in the Administration's attitude to heritage, occurred in the course of the following decade.

\section{The swing of the 1970s}

The 1970s marked what the sociologist Henri Mendras calls the "second French Revolution" and the beginning of what Jean-François Sirinelli refers to as "the decisive twenty years". Let us briefly recall the decade's main features.

French society was experiencing growing urbanisation, fed by a heavy degree of rural flight. The venerable institutions of State education and the Catholic church were losing their sacred character.

These changes were perceptible in the culture field as well. The period following May 1968 was one in which "bourgeois" cultural values were decried. Artistic creation took on a political dimension. The slogan "Live in the country", expressing various forms of neo-ruralism and social utopianism, led to renewed interest in the theme of local life. Local identities were reappropriated in militant fashion, local heritage associations proliferated and there was a surge in amateur ethnology. A change in attitude towards the past occurred, illustrated by the public success of the "New History".

A number of events, beginning in Paris, played a key role in raising public awareness. The demolition in 1971 of the Paris Halles (central food market) built by Baltard was revealing in this respect. These buildings' destruction, just as work was progressing on the Centre Beaubourg, stirred passionate feelings. A movement to reassess the nineteenth century started to bloom. Heritage consciousness emanated from a spectacular evolution in cultural taste and relationship with the past. A willingness to broaden the heritage field was noticeable among many of the parties concerned, including preservation specialists. An instance of this was the organisation in July-September 1968 the winds of May had not yet died down - by the General Association of Public Collection Curators of a symposium on "Heritage and Public Collections". The proceedings of this encounter, published in 1969, formulated a comprehensive definition of heritage. "Heritage is all the natural assets or assets created by man without restriction of time or place. It is the object of culture." This definition composed by the specialists was adopted by the young Socialist Party in its 1972 "Change our Lives" manifesto. The "Change our Lives" programme remained unchanged until the early 1980s. Its intention was to go beyond the fixation on historical monuments. The term "historical monument" was not limited to "works of prestige"; it extended to "the humblest evidence of popular social life and to the technical accomplishments of our forebears". It also embraced "the signposts of our time". The programme laid equally strong emphasis on scientific and technical culture. 
Government policy choices were decisive. Under the Duhamel ministry from 1971 to 1973, the Minister made the change in outlook clear: "It is better to restore a thousand monuments for fifty years than fifty for a thousand years." Jacques Duhamel also stressed the fact that the historical monument, be it chateau, manor-house or church, had lost its class associations. In 1972, in the Revue des monuments historiques, he wrote: "These monuments, once the symbol of our civil strife, are today the sign of a society desperately struggling to preserve a friendly face." The Minister, who was the MP and Mayor of the town of Dole, proposed, although with little success, transferring prime contractorship for work on classified historical monuments to local government. The change in approach occurred at a time when certain cities were beginning to formulate genuine cultural policies. Some, such as Dijon, launched vigorous heritage protection and improvement programmes. ${ }^{17}$

At the beginning of Valéry Giscard d'Estaing's seven-year term as President, a new shift in direction occurred under Michel Guy, State Secretary for Culture. The founder of the Autumn Festival, counselled by art historian Bruno Foucart, undertook a sweeping rehabilitation of the nineteenth century. In 1974, he proposed adding about three hundred 19th and 20th century edifices to the Supplementary Inventory of Historical Monuments. They included not only churches and chateaux but also factories, railway stations, produce markets, museums, theatres, cafes, bandstands and lavoirs. The aim was to bring 19th century architecture into the heritage mainstream. ${ }^{18}$

This line of thinking was greatly strengthened at the end of Valéry Giscard d'Estaing's term. At the launching of Heritage Year in November 1979, Jean-Philippe Lecat, Minister for Culture and Communication, clearly proclaimed his objectives. His definition of heritage leans strongly on the interplay between past and present. "It is like a continuous thread which unites our society's past, present and future and enables it to rise above barrenness and anxiety." The Minister added, "The notion of heritage has broadened. Heritage is no longer cold stones or the glass separating us from exhibits in a museum. It is also the village lavoir, the little country church, local dialects, the charm of family photos, skills and techniques, language, written and oral tradition, humble architecture." The Minister gave official expression to a very inclusive vision of heritage. The President of the Republic took the same view. The Figaro Magazine of 8 March 1980 quoted him as follows: "As to the cultural heritage, it is not made only of stone. It embraces everything that human effort has left us during the course of history, music, dance and song, literature and folk customs, painting and archives - in short, everything that bears witness to humanity down the path of time." ${ }^{19}$ The purpose of this instrumentalisation of heritage was clear; it served the

17 POIRRIER, P., > From the Fine Arts to a Cultural Policy, Dijon 1919 to 1995: The Example of a Regional Capital in France in The European Journal of Cultural Policy, 1996, No.2, pp341-358. See also POIRRIER, P. (Ed.) L'invention du patrimoine en Bourgogne, Editions universitaires de Dijon, 2002.

18 FOUCART, B., A la découverte des nouveaux champs du patrimoine: le 13 octobre de l'anné 1974 in "Science et conscience du patrimoine", NORA, P. (Ed.), Fayard - Editions du patrimoine, Paris, 1997, pp305-320.

${ }^{19}$ Quoted by Y. LAMY, Du monument au patrimoine. Matériaux pour l'histoire politique d'une protection, in "Genèses. Sciences sociales et histoire", March 1993, No.11, pp50-81. 
President's dream of an "advanced liberal society". Here is a brief quotation from his speech at the opening of the Monet exhibition in February 1980: "The idea of heritage must not be a simple matter of preservation. It is the cultural expression of France across time past and for time future." This speech, which coincided with the economic turnabout of the mid-1970s, was reflected in the public policy agenda. It led the Administration to alter its practices. We shall give four very significant examples.

The first was the institution in 1978 of a Heritage Directorate. The Directorate, headed by Christian Pattyn, had the task of coordinating the heritage services, following the loss of the Architecture Directorate, taken over by the Ministry for Equipment. ${ }^{20}$

Next, there was Heritage Year in 1980. Pierre Nora often refers to its seminal influence. The Heritage Year signalled a policy of sensitising public opinion. Its social impact was profound and its features made a strong impression on people at the time. The impact was decentralised and multiform; it stressed the ethnological interpretation of heritage.

The third example - which brings us again to ethnology - was the setting up of the Ethnological Heritage Mission and Council in 1980. Already in 1978, the French Ethnological Society had, at the urging of its President, Isac Chiva, emphasised the importance of the ethnological heritage, which Chiva placed on a par with the artistic, historical and archaeological heritage. He drew attention to the pressing need for making observations in a society that for several decades had undergone the effects of growing urbanisation and industrialisation. ${ }^{21}$ That same year, Hugues de Varine, in a report commissioned by the Ministry's Research and Study Department, confirmed the place of ethnology in the Ministry's new philosophy.

"The Ministry of Culture, as regards national policy and government action in general, has become aware of the fact that the French heritage is not composed solely of the products of cultivated sensibility. It has thus discovered that ethnologists are confined to the University (which does not educate many of them), sociologists (infinitely more numerous) do not concern themselves with heritage, and all the organisers and cultural workers who use the popular heritage for acting in the field are in [the Ministries of] Youth and Sport, Tourism, Agriculture, Education, Environment - in other words, everywhere except in Culture." ${ }^{22}$

Ethnology provides an especially apposite example of the cross-relationship between the discipline's institutional form on the one hand and

${ }^{20}$ LENGEREAU, E., L'Etat et l'architecture, 1958-1981. Une politique publique?, Picard Comité d'histoire du Ministère de la Culture, Paris, 2001.

${ }^{21}$ See I. CHIVA's account, Le patrimoine ethnologique: l'exemple de la France, Encyclopédie Universalis, Symposium, 1990, pp229-241.

${ }^{22}$ De VARINE, H., La place des cultures populaires dans la politique nationale d'action culturelle. Première ébauche d'une analyse du problème et propositions de solutions, SER, Paris, October 1978. My thanks to Daniel Fabre who drew my attention to this report. 
public policy implementation, based on the novel idea of "ethnological heritage", on the other. ${ }^{23}$

Lastly, the Ecomuseum Charter of 4 March 1981 tightened the links between museum policy and the history, behaviour and practices of a territory and its population.

The Ministry of Culture, in making these choices, not only showed that it was in tune with the mood of the day and a diversified public appetite but also contributed powerfully to expanding the notion of heritage. The Ministry was not, however, the only public authority to influence local bodies in the course of the decade. The regional natural parks instituted in the late 1960s also played an important role. The 1967 Decree setting up the regional natural parks stipulated that an area could be placed in this category by reason of the "quality of its natural and cultural heritage". Scholars like Claude Lévi-Strauss, Georges-Henri Rivière and Isac Chiva argued that the parks should take account of the rural heritage and interpret the idea of heritage more broadly. Georges-Henri Rivière, Director of the Museum of Popular Arts and Traditions, acted as a "go-between" on emerging heritage issues between the international organisations (Icomos, UNESCO, Council of Europe) and their expressions at the national level. ${ }^{24}$

\section{The consolidation of the $1980 \mathrm{~s}$}

The 1980s were a period more of development of existing trends than of a change in direction. ${ }^{25}$ The Left's coming to power was the occasion for reasserting the legitimacy of broadening the definition of heritage. Even so, there was an element of disputing the past in a speech by Presidential candidate François Mitterrand just before the second round of the Presidential elections. He condemned the heritage policy of the previous Presidency, dismissing it as a policy of communication, and treated the teaching of history, then under debate, as an insult to the nation's memory. ${ }^{26}$

The heritage policy conducted by the freshly-installed team at the Ministry of Culture incorporated the ideas outlined in a whole series of reports. Max Querrien, former Director for Architecture, drew up an official report entitled "For a New Heritage Policy" which was submitted to Minister of Culture, Jack Lang, in June 1982. Max Querrien advocated a comprehensive policy that would include all the Ministry's heritage sectors rather than just the ones covered by the Heritage Directorate. The primary aim was to "breathe life" into heritage. Max Querrien

\footnotetext{
${ }^{23}$ FABRE, D., La politique de l'ethnologie du Ministère de la Culture depuis les années soixante-dix in L. VADELORGE and P.POIRRIER (Eds) Histoire des politiques du patrimoine, XIXe-XXe siècles, Comité d'histoire du Ministère de la Culture - La Documentation Française, Paris, 2003 (forthcoming).

${ }^{24}$ DESVALLEES, A., Emergence et cheminement du mot patrimoine in "Musées et collections publiques de France" No.208, September 1995, pp6-25.

${ }^{25}$ See POIRRIER, P., Patrimoine versus "Tout culturel" (1981-1993) in L. VADELORGE and P. POIRRIER (Eds) Histoire des politiques du patrimoine.

${ }^{26}$ MITTERRAND, F., Le premier des patrimoines c'est l'Homme in "Les Nouvelles Littéraires", 7 May 1981.
} 
insisted upon the unity of the cultural heritage. The priority areas were those, such as ethnology and archaeology, which extended beyond the conventional preoccupation with historical monuments. $^{27}$

The policy was expounded at a symposium held in 1984 under the title "Historical Monuments Tomorrow". The intention of the symposium, organised by the Heritage Directorate, was to provide a platform for all the heritage partners, ranging from the specialists to the general visitor.. The Heritage Directorate called upon academics, such as Jacques Le Goff, François Loyer, Maurice Agulhon and Madeleine Rebérioux, whose sympathies lay on the side of the new parliamentary majority. The programme of the first day gives an idea of the Heritage Directorate's strategy choices: "An Outline of the General Inventory" by André Chastel, followed by eight round tables, the first three of which underscored the widening of the heritage field by dealing with rural architecture, the technical and industrial heritage, and the historical extension of the concept of heritage. $^{28}$

In 1987, when the symposium proceedings were published, the periodical "Terrain" devoted a long article to their content. The article, signed Eugène Ollivier, a pen-name used by Jean-Michel Leniaud, dwelt on a crucial point what should be the respective roles of the State and civil society as regards heritage? The author, who is an expert on the founding principles of 19th century government policy, noted the major changes that inevitably altered the perception of heritage policy. "Nowadays, the Nation is no longer a predominant factor; nor are the Fine Arts. The almightiness of the State is called into question. (...) The values that sub-tend conservation are no more the property of the government." The universality of heritage had taken the place of the elitist and centralising idea of the "historical monument". "The State's job is not to impose its ideas on the citizen; it is to respect pluralism and make groups respect that pluralism." This approach marked a break with the habitual position adopted by heritage specialists, who more often than not take shelter behind technical considerations and hardly ever make reference to the philosophy underlying official practice. The conclusion was both terse

and thought-provoking: "This is perhaps the message conveyed, whether consciously or not, by the symposium. It is a message which encloses the spirit of ethnology - the heritage item preserves its status only insofar as the social group which provides its context continues to accept it. We are therefore led to believe that the true yardstick of heritage is not art or history but the social group's inner conviction that the item in question effectively forms part of its heritage." 29 This summing-up produced heated reactions - hostile in Historical Monument Service circles, which rejected this recognition of a shift from the notion of historical monument to the notion of heritage, favourable among ethnologists, who regarded it as a "seal of approval" for the rightness of their action.

27 QUERRIEN, M., Pour une nouvelle politique du patrimoine, La Documentation Française, Paris, 1982.

${ }^{28}$ Les monuments historiques demain, Ministry of Culture and Communication, Paris, 1987.

29 OLLIVIER, E., Les monuments historiques demain, in "Terrain", No.9, October 1987, pp124-127. Text reused by J-M. LENIAUD, Chroniques patrimoniales, Norma, Paris, 2001, pp285-290. 
Over the next few years, several measures aimed at bringing the notion of "new heritage fields" to the fore were taken by the government. The approach became clearly defined in the late 1980s. The areas covered by the measures ranged from knowledge and the scientific inventory to public awareness-raising and classification procedures. It was also at this time that protection campaigns, organised by theme, were launched.

The Léotard Ministry (1986-1988) did not oppose the broadening of the heritage concept head-on, although a return to "monumentality" was discernible. Heritage protection emerged as one of the new Ministry's priorities. Its thinking focussed on the uses of heritage. The working group "Patrimoine 2000", directed by Serge Antoine, took heritage activity-organising as its central theme. The widening of the heritage field was nevertheless acknowledged: "While heritage may be said to be what remains once culture has passed by, what may be said of its range? Not only archives, collections, monuments, furnishings, city centres and landscapes but also values, languages, lifestyles and education systems are packed into it. The cultural ocean is boundless." The report's author was careful to add, however: "It would all the same be useful to set matters in perspective. (...) The catch-all concept is still vague and broad. Too much so?" The report excluded intangibles - "the invisible heritage" - and concentrated on "the places of time". The author stresses the continuing need to protect the rural heritage and the heritage of the 20th century. ${ }^{30}$

The Left's return to power in 1988 signalled a more pronounced interest by the Ministry of Culture in heritage affairs. The appointment of one of the Minister's confidants, Christian Dupavillon, to head the Heritage Directorate was seen by many as the sign of a real conversion to heritage ideals. In Chambord, on 6 September 1988, Jack Lang laid down the basic principles of a "stronger policy". The Ministerial agenda called for expanded fields of action, ranging from the rural heritage to a category called "places of memory". The new heritage fields were listed in a compendium Regards sur le patrimoine issued in 1992: The 1850-1950 Heritage, The Industrial and Technical Heritage, The Rural Heritage, Skills, Social Rites and Practices, Places of Worship, Places of Memory, Parks and Gardens. ${ }^{31}$

A series of official measures backed up these principles. Heritage registration was deconcentrated in the mid-1980s by the creation of Regional Historical, Archaeological and Ethnological Heritage Commissions (Corephae) designed to improve the treatment of neighbourhood heritage, often tied up with local identity. The work of "ethnological counsellors" - within the Regional Cultural Affairs Directorates (DRAC) also helps to give scientific standing to the new heritage categories and provide position material on heritage. The DRAC ethnologists thus have a task which spans heritage and local identity. Heritage now goes to serve more than national history; it plays a part in today's social structures and sense of identity. As Daniel Fabre points out, ethnology takes root in the present: "Whenever the past comes on stage, it is the 'present perfect' of the

${ }^{30}$ ANTOINE, S. et al., Promouvoir le patrimoine français pour l'an 2000, Report intended for Mr Philippe de Villiers, State Secretary for Culture and Communication, CNMHS, Paris, 1987.

31 Regards sur le patrimoine, RMN, Paris, 1992. 
grammar-books. For an ethnologist the past leaves a trace, but remains active, still present in certain respects." 32 This new breadth is noticeable in the area of commemorations - as Pierre Nora puts it, the restricted commemoration has given way to the generalised one. The annual brochure issued by the Delegation for National Celebrations bears witness to this enlargement. Heritage also exists in the future tense. Major buildings and works programmes are presented as a way of recognising the merits of modern creative architecture. They also figure, under the title "Creating and Organising Tomorrow's Heritage", in the official record of the 1990s.

In 1992, Christian Dupavillon supplied a theoretical framework for this approach. The Heritage Director mentioned the relation between heritage and time. In his view, heritage is "not a past but a present of the past". Heritage ceased being regarded as a vertical phenomenon, like a legacy handed down from father to son. Dupavillon advocated a "horizontal" definition: "Heritage is the presence of the past in the present, a legacy transmitted from the father to other fathers." 33

What role did culture policy play in this expansion? Its role hinged on two types of factor. First, the State, represented by the Ministry of Culture, was clearly responding to a social demand that had taken shape in the 1970s. The Ministry also helped, by adopting the positions defended by politicians and implementing the numerous administrative procedures of the 1980s, to legitimise the broadening of the heritage notion.

The result was not disconnected from rivalries inside the Ministry and even inside the Heritage Directorate. The Ministry of Culture's high degree of compartmentalisation - on one side, heritage, on another, museums, and on yet another, archives and libraries - induces intellectual segregation. On this account, collective reflection on heritage within the Ministry of Culture is rare. In the case of heritage, as managed by the Heritage Directorate, it is obvious that the State played a major part in accrediting the new attitudes, especially as it is a field where the State has for a long time been pleased to exert a quasi-regal influence.

In the years following the 1990s, a certain unease became noticeable within the Ministry of Culture. The Rigaud report in 1996 spoke of the "danger posed by irresistible heritage pressures". Jacques Rigaud was expressing the sentiments of both local office-holders and Ministry senior officials. ${ }^{34}$ The theme chosen in 1997 for the annual "Entretiens du Patrimoine (Heritage Colloquium)" gave a fair indication of these worries: "Passions concerning Identity". A look at the proceedings shows that the passions were largely on the side of condemnation. $^{35}$ In 1998, the idea of "monument abuse", given public currency

32 FABRE, D., Le patrimoine, l'ethnologie in P. NORA (Ed.), Science et conscience du patrimoine, Fayard-CNMHS, Paris, 1997, pp59-72.

${ }^{33}$ DUPAVILLON, C., Qu'est-ce que le patrimoine? in "Regards sur le patrimoine", RMN, Paris, 1992, pp12-17.

${ }^{34}$ RIGAUD, J., Pour une refondation de la politique culturelle, La Documentation Française, Paris, 1996.

${ }^{35}$ LE GOFF, J. (Ed.), Patrimoine et passions identities, Editions du patrimoine - Fayard, Paris, 1998. 
by Régis Debray, was yet another manifestation of the uncertainties prevailing inside the Heritage Directorate. ${ }^{36}$ Most of the speakers - and not the least among them, since the head of the Heritage Directorate, François Barré, was one - fell in step with this view. They quickly slid from monument abuse to heritage abuse. The semantic drift was an easy one to slip into. ${ }^{37}$ Jean-Michel Leniaud interpreted the diffidence towards heritage extension as a "return to the monumental". ${ }^{38}$

Today, even though the State exercises considerable influence in terms of regulation and by virtue of its expertise, it is less and less in control of how heritage is defined.

The rising power of local government is one of the most important factors in the present situation. It raises the problem of the respective competencies of the various rungs in the hierarchy of those entitled to take action. An operation launched by the Ministry of Culture in December 2000, "The Cultural Decentralisation Protocols", demonstrated the government's wish to take decentralisation a step further. On 26 June 2001, the National Assembly approved and gave official status to these novel but pragmatic experiments by adopting a Cabinet amendment to a Bill on "Neighbourhood Democracy". The amendment, which associated the experiments with the decentralisation process, was aimed at granting more responsibility to local and territorial bodies in the field of heritage. The MPs unanimously voted for the establishment of an experimental system of competency devolution, budget transfers and partnership development with regard to the inventory, conservation, restoration and exploitation

of historical monuments. The experiments' goal is to bring about decentralising changes, on sites chosen by volunteering local bodies, that will clarify central and local government responsibilities in the sector. ${ }^{39}$ The experiment protocols, signed for a period of three years, will be modelled on the decentralisation protocols venture already launched by the Ministry of Culture and Communication in 2001. Seven of these protocols were concluded in 2001 with four Regions and three Departments.

The growing role of international institutions and the European Union cannot but accentuate the dissociation of heritage from the nation-state. The framing of a Europe-wide heritage policy is one of the EU's main challenges. Political Europe, which suffers from a real "democracy deficiency", will have to develop forms of common cultural representation. Other new questions are

\footnotetext{
${ }^{36}$ DEBRAY, R. (Ed.), L'abus monumental, Editions du Patrimoine - Fayard, Paris, 1998.

${ }^{37}$ On this topic, see DE SAINT-PULGENT, M., Le patrimoine au risque de l'instant in "Les Cahiers de Médiologie, No.11", 2001. (Proceedings of the Cerisy colloquium, June 2000.) The former heritage director deplored the shifts being made: Heritage had ceased being fully concerned with what was universal, generational transmission, the long term, and history; it had become narrowly focussed on identity, tainted by cultural relativism, immediacy and even fashion. ${ }^{38}$ LENIAUD, J-M., Les archipels du passé. Le patrimoine et son histoire, Fayard, Paris, 2002, pp $307-320$.

See the speech by Michel DUFFOUR, State Secretary for Heritage and Cultural Decentralisation, on the occasion of the national seminar devoted to the cultural decentralisation protocols held on 3 July 2001, reproduced in P. POIRRIER, Les politiques culturelles en France, La Documentation Française, Paris, 2002, pp597-598.
} 
posed by the spread of commercial values, sustained on a global scale by multinational cultural industries.

Heritage policy, provided it is not based on populist distortions of an in-turned culture, can help in bridging the cultural "divide" that exists in France as in most Western democracies. The sociologist Jean-Claude Kaufmann clearly defined the issue just after the Presidential elections in April 2002: "France is cut in half - not socially as it used to be, but culturally, and irremediably. One the one hand, you have the culturally endowed moderns open to all the new and exciting questions of the day. On the other, you have the ashamed suffering of those who do not understand anything about all this agitation, the silent withdrawal into tacky little houses. One the one hand, the young, imbued with multi-culturism, who dream of sinking their teeth into the future; on the other the new counter-revolution of the grey-polls." 40

\section{REFERENCES :}

BABELON J.-P. et CHASTEL A., La notion de patrimoine, Paris, Editions Liana Levi, 1994. (Première édition : Revue de l'art, 1980).

BALSAMO I., André Chastel et l'“ aventure " de l'Inventaire dans P. NORA (Dir.), Science et conscience du patrimoine, Paris, Fayard-Editions du patrimoine, 1997, p. 257-267.

BERCE F., Des Monuments historiques au Patrimoine du XVIIIe siècle à nos jours, Paris, Flammarion, 2000.

BODIGUEL J.-L., L'implantation du ministère de la culture en région. Naissance et développement des directions régionales des affaires culturelles, Paris, La Documentation française-Comité d'histoire du ministère de la Culture, 2000.

CHIVA I, Le patrimoine ethnologique : l'exemple de la France, Encyclopédie Universalis, Symposium, 1990, p. 229-241.

CHOAY F., L'Allégorie du patrimoine, Paris, Seuil, 1992.

DEBRAY R. (Dir.), L'abus monumental, Paris, Editions du patrimoine-Fayard, 1999.

DESVALLEES A., Emergence et cheminement du mot patrimoine, Musées et collections publiques de France, septembre 1995, n² 208, p. 6-25.

DUBOIS V., La politique culturelle : genèse d'une catégorie d'intervention publique, Paris, Belin, 1999.

FABRE D, La politique de l'ethnologie du ministère de la Culture depuis les années soixante-dix dans L. VADELORGE et P. POIRRIER (dir.), Histoire des politiques $d u$ patrimoine, XIXe-XXe siècles, Paris, Comité d'histoire du ministère de la Culture-La Documentation française, 2003. (à paraître).

FABRE D, Le patrimoine, l'ethnologie dans P. NORA (Dir.), Science et conscience $d u$ patrimoine, Paris, Fayard-CNMHS, 1997, p. 59-72.

FOUCART B, A la découverte des nouveaux champs du patrimoine : le 13 octobre de l'année 1974 dans P. NORA (Dir.), Science et conscience du patrimoine, Paris, Fayard-Editions du patrimoine, 1997, p. 305-320.

LAMY Y., Du monument au patrimoine. Matériaux pour l'histoire politique d'une protection, Genèses. Sciences sociales et histoire, mars 1993, $\mathrm{n}^{\circ} 11$, p. 50-81.

LAURENT X., La politique du patrimoine monumental d'André Malraux à Michel Guy (1958-1974), Ecole nationale des Chartes, thèse pour le diplôme d'archiviste paléographe, 2002.

Le GOFF J. (Dir.), Patrimoine et passions identitaires, Paris, Editions du patrimoine-Fayard, 1998.

${ }^{40}$ KAUFMANN, J-C., Les nouveaux barbares, in "Le Monde", 26 April 2002. 
LENGEREAU E., L'Etat et l'architecture, 1958-1981, Une politique publique ?, Paris, Picard-Comité d'histoire du ministère de la culture, 2001.

LENIAUD J.-M., Les archipels du passé. Le patrimoine et son histoire, Paris, Fayard, 2002.

LENIAUD J.-M., Chroniques patrimoniales, Paris, Norma, 2001.

LENIAUD J.-M., L'utopie française. Essai sur le patrimoine, Paris, Ed. Mengès, 1992.

NORA P. (Dir.), Science et conscience du patrimoine, Paris, Fayard-CNMHS, 1997.

OLLIVIER E., Les monuments historiques demain..., Terrain, octobre 1987, $\mathrm{n}^{\circ}$ 9, p. 124-127. Texte repris dans J.-M. LENIAUD, Chroniques patrimoniales, Paris, Norma, 2001, p. 285-290.

PIRE J.-M., Les origines du volontarisme culturel français. Sociologie de la politique culturelle sous la monarchie de Juillet, Université de Paris VII, thèse de sociologie, 1999.

POIRRIER P., L'Etat et la culture en France au XXe siècle, Paris, Le Livre de Poche, 2000.

POIRRIER P. (Dir.), L'invention du patrimoine en Bourgogne, Dijon, Editions universitaires de Dijon, 2002.

POIRRIER P. et VADELORGE L., Histoire des politiques du patrimoine. Une histoire à écrire, Les Cahiers de la ligue urbaine et rurale, 2e semestre 2002.

POIRRIER P., Bibliographie de l'histoire des politiques culturelles. France, XIXe-XXe siècles, Paris, La Documentation française-Comité d'histoire du ministère de la Culture, 1999.

POIRRIER P., From the Fine Arts to a Cultural Policy Dijon 1919 to 1995 : The example of a Regional Capital in France, The european journal of cultural policy, 1996, n 2, p. 341-358.

POIRRIER P., Les politiques culturelles en France, Paris, La Documentation française, 2002.

POIRRIER P., Patrimoine versus "Tout culturel" (1981-1993), dans L. VADELORGE et P. POIRRIER (Dir.), Histoire des politiques du patrimoine, XIXe-XXe siècles, Paris, Comité d'histoire du ministère de la Culture-La Documentation française, 2003. (à paraître).

POULOT D., Patrimoine et musées. L'institution de la culture, Paris, Hachette, 2001.

RIGAUD J., Pour une refondation de la politique culturelle, Paris, La Documentation française, 1996.

ROUSSO H (Dir.), Le regard de l'histoire. L'émergence et l'évolution de la notion de patrimoine au cours du XXe siècle en France, Paris, Fayard, 2002.

SAINT-PULGENT M. de, Le patrimoine au risque de l'instant, Les Cahiers de Médiologie, 2001, $n^{\circ} 11$.

URFALINO P., L'invention de la politique culturelle, Paris, Comité d'histoire du ministère de la culture-La Documentation française, 1996. 